\title{
PENERAPAN EKOLOGI, SIMBIOSIS, DAN BIOFILIK PADA RUANG PEMULIHAN DEPRESI PASCAPANDEMI
}

\author{
Editha Santika ${ }^{1)}$, Rudi Trisno ${ }^{2)}$ \\ 1)Program Studi S1 Arsitektur, Fakultas Teknik, Universitas Tarumanagara, edithasantika@gmail.com \\ 2) Program Studi S1 Arsitektur, Fakultas Teknik, Universitas Tarumanagara, rudy@ft.untar.ac.id
}

Masuk: 04-07-2021, revisi: 15-08-2021, diterima untuk diterbitkan: 23-10-2021

\begin{abstract}
Abstrak
Kesehatan mental yang baik adalah kondisi ketika batin kita berada dalam keadaan tenteram dan tenang, sehingga dapat menikmati kehidupan sehari-hari dan menghargai orang lain di sekitar. Depresi adalah penyakit dengan pengidap paling banyak di Indonesia yang menyebabkan masalah dalam kehidupan sehari-hari, tidak hanya dapat merusak interaksi atau hubungan dengan orang lain, namun juga dapat menurunkan prestasi di sekolah dan produktivitas kerja. Tujuan dari proyek ini adalah untuk memberikan fasilitas penyembuhan yang memadai dan layak bagi pasien gangguan kesehatan di Jakarta dengan bangunan yang telah disesuaikan pada masa pandemi dengan inovasi dalam pemulihan kesehatan mental melalui pendekatan ekologi. Metode yang digunakan untuk mendukung proyek ini adalah prinsip bangunan ekologis dari Heinz Frick, metode simbiosis dari Kisho Kurokawa, dibantu pula dengan biofilik dan healing architecture. Kesimpulan dari proyek ini adalah untuk menciptakan wadah (bangunan dan lingkungan) yang dapat membantu pemulihan kesehatan mental yang dapat menjadi jembatan antara manusia dan lingkungan dan menghubungkannya sedekat mungkin dan menciptakan suasana baru di masa pandemi ini.
\end{abstract}

Kata kunci: biofilik; ekologi; pasca pandemi; pemulihan depresi; simbiosis

\begin{abstract}
Good mental health is a condition when our mind is in a calm and calm state, so we can enjoy everyday life and appreciate other people around us. Depression is a mental illness with biggest cases in Indonesia that causes problems in everyday life, not only can damage interactions or relationships with other people but can also reduce achievement at school and work productivity. The purpose of this project is to provide adequate and appropriate healing facilities for patients with health problems in Jakarta with buildings that have been adapted to the pandemic era with innovations in mental health recovery through an ecological approach. The methods used to support this project are Heinz Frick's ecological building principles, Kisho Kurokawa's symbiotic method, assisted by a biophilic and healing architecture. The conclusion of this project is to create a space (building and environment) that can help with mental health healing that can be a bridge between humans and the environment and connect them as closely as possible and create a new atmosphere in this pandemic era.
\end{abstract}

Keywords: biophilic; ecology; healing depression; post-pandemic; symbiosis

\section{PENDAHULUAN Latar Belakang}

Sudah satu tahun belakangan ini, mulai dari awal 2020, Indonesia berperang melawan pandemi, situasi menjadi jauh lebih parah dari keadaan sekarang ini. Dampaknya dapat dirasakan pada lingkungan yang semakin rusak karena bertambahnya sampah, ekonomi berantakan, angka kematian terus meningkat, begitu juga dengan kesehatan mental yang kian memburuk. Para pelajar sudah bosan dan stres belajar di rumah, para pemilik usaha menggulung tikar, para pegawai di PHK, banyak yang beralih profesi demi bertahan hidup. Lebih parahnya, ditinggal 
orang tersayang dan tidak dapat memberikan salam perpisahan untuk terakhir kalinya demi keselamatan diri dan orang lain yang masih bertahan. Trauma, kesepian, perubahan sikap dan kehilangan harapan hidup menjadi dampak besar yang diakibatkan oleh virus kecil ini. Gejala stres pascatrauma yang menonjol adalah merasa terpisah atau tidak terhubung dengan orang lain dan merasa terus waspada. Adapun gejala lain seperti mati rasa, ledakan kemarahan atau mudah kesal, sulit tidur, dan masalah konsentrasi. (PDSKJI, 2020)

Usaha dalam mempertahankan Kesehatan mental kian lebih berat saat pandemi Covid-19 melanda. PBB mengisyaratkan adanya krisis kesehatan jiwa akibat pandemi. Kepala Staf Presiden, Moeldoko menyatakan bahwa selama periode 16 - 30 Maret 2020 saja ada 59 kasus kekerasan, perkosaan, dan pelecehan. Sementara Kabagpenum Polri, Kombes Asep Adi Saputra mengatakan peningkatan angka kejahatan selama masa pandemi Corona sekitar 11,8 persen (CNN Indonesia, 2020). (Indonesia, CNN, 2020)

Lingkungan hidup adalah kesatuan ruang dengan semua benda, daya, keadaan, dan makhluk hidup, atau eco, oikos, atau tempat bernaung. Sayangnya, kesatuan ini sudah mulai pudar dan hilang rasa. Kesejahteraan mental maupun fisik masyarakat masih sangat bergantung pada kontak dengan lingkungan alam. Arsitektur harus kembali kepada esensi dalam meningkatkan kualitas hidup penggunanya tanpa membahayakan keberlanjutan generasi berikutnya. Bangunan ekologis adalah cara yang inovatif untuk merancang tempat di mana kita hidup, bekerja dan belajar yang bertujuan untuk menciptakan ruang hidup yang sehat dan berpengaruh baik bagi masyarakat.

\section{Rumusan Permasalahan}

Mengacu pada latar belakang, maka menghasilkan dua rumusan masalah utama yang hendak diselesaikan dalam proyek. Pertama, bagaimana arsitektur ekologis dapat memberikan kontribusi perihal pemulihan depresi di masa sekarang dan yang akan datang? Kedua, metode dan desain seperti apakah yang dapat memenuhi standar dan membantu Pemulihan pasien depresi?

\section{Tujuan}

Tujuan dari proyek ini adalah dapat menjadi fasilitas penyembuhan yang memadai dan layak bagi pasien gangguan kesehatan di Jakarta dengan bangunan yang telah disesuaikan pada masa pandemi, memberikan inovasi dalam pemulihan kesehatan mental melalui pendekatan ekologi, mencoba menekan angka pasien gangguan kesehatan mental dan merancang bangunan yang sebisa mungkin meminimalkan pemakaian energi dan dapat menghasilkan energi.

\section{Manfaat}

Proyek diharapkan dapat memberikan fasilitas penyembuhan yang memadai dan layak bagi pasien depresi di Jakarta dengan bangunan yang telah disesuaikan pada masa pandemi, memberikan inovasi dalam pemulihan kesehatan mental melalui pendekatan ekologi, menekan angka pasien depresi dengan prinsip arsitektur ekologis.

\section{Ekologi}

Ekologi terdiri dari dua kata berbahasa Yunani yakni "oikos" adalah rumah tangga atau cara bertempat tinggal dan "logos" bersifat ilmu atau ilmiah. Ekologi didefinisikan sebagai ilmu yang mempelajari tentang hubungan timbal balik antara makhluk hidup dan lingkungannya (Frick, 1998). Setiap pembangunan merupakan suatu pembaharuan atau perubahan lingkungan. Perhatian atas perubahan lingkungan berarti perhatian atas arsitekturnya dan atas kualitas kehidupan manusia. Jika membandingkan kualitas lingkungan pada masa lalu dengan keadaan sekarang, dapat dilihat bahwa kualitasnya menurun. 


\section{Simbiosis}

Simbiosis berasal dari bahasa Yunani 'sumbiōsis' dengan yang berarti 'a living together' atau 'live together' dengan kata dasarnya 'sumbios' yang dalam bahasa Inggris 'companion'. Kata companion dapat diartikan sebagai seseorang dengan kawannya bepergian dan menghabiskan banyak waktu. Ini berarti bahwa ada dua makhluk yang hidup bersama karena memiliki dimensi kepentingan. Dalam ilmu biologi, simbiosis dapat diartikan sebagai interaksi antara dua organisme berbeda yang hidup dalam hubungan fisik yang erat, biasanya untuk keuntungan keduanya (Sutanto, 2020). Dalam konsep Kurokawa (1994), ia mencoba untuk mengombinasikan hubungan simbiosis ini pada manusia maupun dalam kegiatan ruang terbuka, sehingga dapat memberikan nilai tambah bagi lingkungan Hidup. (Trisno \& Lianto, 2019)

\section{Biofilik}

Desain Biofilik adalah pengembangan dari green design yang memerhatikan ekologi dengan kehidupan alam, bukan hanya menciptakan bangunan yang ramah lingkungan dan juga hemat energi, tetapi bertujuan menciptakan bangunan yang bisa bermanfaat bagi kesehatan. Desain biofilik dapat dijadikan strategi dalam merancang "DERANA" Ruang Pemulihan Depresi di Masa dan Pascapandemi karena memiliki tujuan yang sama dengan metode simbiosis.

\section{Ruang Pemulihan}

Fungsi bangunan yang dipilih berupa bangunan rehabilitasi bagi pasien gangguan jiwa. Kata 'Rehabilitasi' dalam Kamus Besar Bahasa Indonesia adalah pemulihan kepada kedudukan. Maka, Ruang Pemulihan dipilih menjadi judul proyek karena dinilai pas dengan tujuan dari bangunan. Kata 'Ruang' diartikan sebagai rongga yang tidak berbatas, tempat segala yang ada dan 'Pemulihan' diartikan sebagai proses, cara, perbuatan memulihkan: (kembali baik, sehat, sebagai semula; sembuh atau baik kembali). Fasilitas Pemulihan Depresi yang disediakan terdiri dari jasa konsultasi dan konseling, rawat inap, kegiatan terapeutik, dan kegiatan alam seperti interaksi dengan hewan, tumbuhan dan aplikasi biopori yang seluruh kegiatannya ditujukan untuk mempercepat proses Pemulihan pasien.

\section{Penerapan Konsep Ekologi, Simbiosis dan Biofilik ke dalam Ruang Pemulihan.}

Desain yang berdasar pada prinsip ekologi, penggunaan metode desain simbiosis, dan desain biofilik diharapkan dapat menciptakan dan mengoptimalkan suasana ruang yang diharapkan hadir di Ruang Pemulihan Derana ini. Penerapan ekologi pada bangunan bertumpu pada enam aspek dasar yakni: Energi dan emisi, Adaptasi, Ketahanan (resiliensi), Keberlanjutan, Teknologi baru, dan Kontekstual. Penggunaan metode simbiosis diaplikasikan dengan adanya interaksi antar lima kingdom makhluk hidup yang berada di lingkungan bangunan guna saling memberikan dampak positif satu sama lain. Terakhir, prinsip biofilik desain menekankan pada elemen alam, aksen lengkung dan permainan multi sensori yang berefek baik pada pasien depresi. Desain biofilik hadir dengan memenuhi sepuluh aspek desain biofilik.

\section{KAJIAN LITERATUR}

\section{Bangunan konsep Ekologi}

'Beyond' Ecology menjadi sebuah kemampuan untuk melihat lingkungan binaan yang penuh dengan objek ekosistem dan bangunan yang dirancang harus sebagai rumah bagi manusia. Sehingga, menghasilkan konsep baru tentang keruangan, bangunan yang lebih lokal. Pada dasarnya, kemajuan teknologi akan dipercepat. Ruang menjadi fleksibel karena adanya perubahan ekosistem yang sedang berlangsung.

Setiap pembangunan merupakan suatu pembaharuan atau perubahan lingkungan. Perhatian atas perubahan lingkungan berarti perhatian atas arsitekturnya dan atas kualitas kehidupan 
manusia. Jika membandingkan kualitas lingkungan pada masa lalu dengan keadaan sekarang, dapat dilihat bahwa kualitasnya menurun. (Gambar 1)

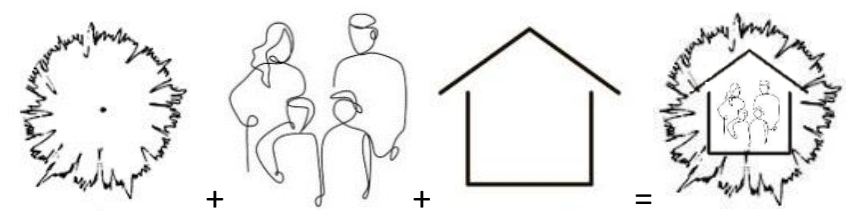

Gambar 1. Diagram kaitan lingkungan alam dan manusia

Sumber: Buku Arsitektur Ekologis, Heinz Frick

\section{Arsitektur Ekologis}

Arsitektur yang ekologis akan tercipta bila di dalam proses berarsitektur digunakan pendekatan desain yang ekologis (alam sebagai basis desain). Proses pendekatan desain arsitektur yang mengombinasikan alam dengan teknologi, menjadikan alam sebagai basis desain, strategi konservasi, perbaikan lingkungan, dan bisa diterapkan pada semua tingkatan dan skala untuk menghasilkan suatu bentuk bangunan, lanskap, permukiman dan kota yang revolusioner dengan menerapkan teknologi dalam perancangannya.

Arsitektur ekologis menurut Heinz Frick (Frick, 1998), memiliki sifat-sifat: Pertama, Holistis yang berhubungan dengan sistem keseluruhan, sebagai suatu kesatuan yang lebih penting daripada sekedar kumpulan bagian. Kedua, Memanfaatkan pengalaman manusia (tradisi dalam pembangunan), dan pengalaman lingkungan alam terhadap manusia. Ketiga, Pembangunan sebagai proses dan bukan sebagai kenyataan tertentu yang statis. Keempat, Kerja sama antara manusia dengan alam sekitarnya demi keselamatan kedua pihak (Gambar 2).

Paramteter 'Beyond Ecology'

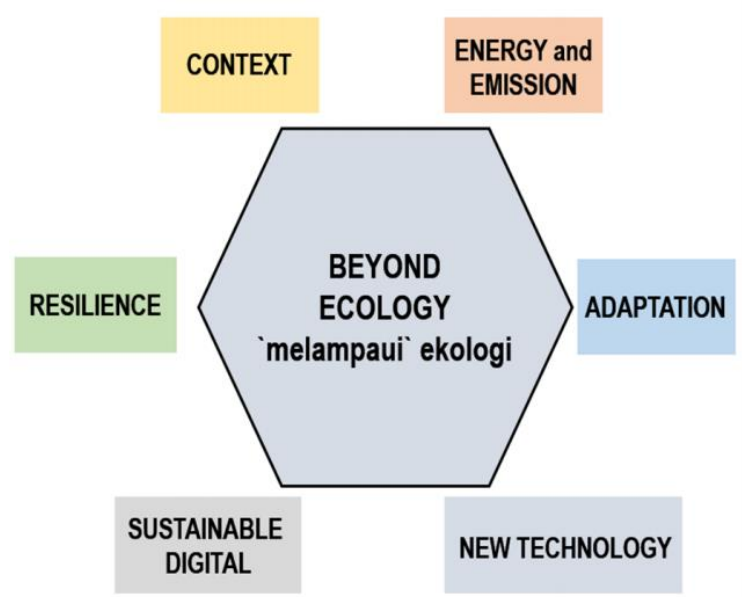

Gambar 2. Parameter dalam arsitektur menuju 'Beyond Ecology'

Sumber: Dromos Oikos - Agustinus Sutanto

Energy and emission: adalah kemampuan untuk menerapkan zero $\mathrm{CO} 2$ emission dalam mengoperasionalkan bangunan dan meminimalisasi efek karbon dalam material dan konstruksi. Adaptation: adalah kemampuan untuk melakukan riset dan desain yang berkaitan dengan berbagai dampak, seperti naiknya suhu bumi, naiknya permukaan laut, kekeringan, banjir, kelangkaan pangan, perubahan populasi.

Resilience: adalah kemampuan untuk membangun kelanjutan 'hunian' dan Pemulihan cepat setelah kejadian guncangan, bencana alam, gangguan listrik atau iklim.

Sustainable digital: adalah kemampuan untuk melihat data-data lingkungan sebagai big data dalam menentukan taktik dan strategi dalam membangun kualitas spasial. 
New technology: adalah kemampuan memanfaatkan teknologi terbaru untuk meningkatkan kualitas dan terapan ruang - konstruksi dan program bangunan.

Context: adalah kemampuan dalam melihat posisi 'tempat' dalam hubungan dengan lingkungan (flora-fauna, biotic-abiotic) di mana sebuah konfigurasi keruangan akan ditempatkan.

\section{Bangunan dengan metode Simbiosis}

Pada proyek ini lebih berfokus pada interaksi yang dihasilkan dari lima jenis makhluk hidup yang dilibatkan ke dalam berbagai program di dalam bangunan. Melakukan simbiosis pada hal yang berbeda bukan berarti menyatukan perbedaan, namun justru untuk mampu menghasilkan hal baru oleh adanya penggabungan. Sebab, pada dasarnya teori simbiosis bukanlah sebuah teori dominasi, di mana yang terkuat dari dua elemen bertentangan memimpin yang lemah. (Wuaten, Siregar, \& Takumansang, 2014)

Satu prinsip yang dari enam prinsip simbiosis menurut Kisho Kurokawa yang digunakan dalam proyek bangunan ini adalah prinsip ke-enam yakni Symbiosis of Man and Nature. Segala benda buatan manusia seperti danau buatan, dermaga, hutan buatan, kota maupun teknologi seiring dengan waktu juga menjadi bagian dari alam. Segala sesuatu ciptaan Tuhan adalah alam sedangkan segala buatan manusia adalah artifisial yang tidak tahan lama. Tujuan pemakaian metode simbiosis adalah untuk menunjukkan perlunya mendesain sesuai dengan alam dan untuk menganalisis hubungan antara lingkungan buatan dan alam. (Sutanto, 2020)

\section{Bangunan dengan desain Biofilik}

Biofilik merupakan sebuah pendekatan untuk menciptakan desain yang dapat menghasilkan interaksi antara manusia dan alam di dalam bangunan dan lansekap modern. (Azizah \& Jaya, 2016) Terdapat 14 pola yang dimiliki oleh Desain Biofilik (Gambar 3). Dalam rancangan bangunan diaplikasikan sepuluh aspek biofilik, yakni: elemen air, kompleksitas dan keteraturan, pencahayaan, pola dan bentuk biomorfik, visual alam, hubungan dengan sistem alam, stimulasi sensorik non ritmik, non-visual alam, dan material alam, variasi suhu dan aliran angin. (Downton, Jones, Zeunert, \& Roos, 2017)

\begin{tabular}{ll|}
\hline Context & 14 Patterns \\
\hline NATURE IN THE SPACE & 1 Visual Connection with Nature \\
& 2 Non-Visual Connection with nature \\
& 3 Non-Rhythmic Sensory Stimuli \\
& 4 Thermal and Airflow Variability \\
& 5 Presence of Water \\
& 6 Dynamic and Diffuse Light \\
\hline NATURAL ANALOGUES & 7 Connection with Natural Systems \\
\hline & 8 Biomorphic Forms and Patterns \\
\hline NATURE OF THE SPACE & 9 Material Connection with Nature \\
& 10 Complexity and Order \\
& 11 Prospect \\
& 12 Refuge \\
& 13 Mystery \\
& 14 Risk / Peril \\
\hline
\end{tabular}

Gambar 3. Empat belas pola desain biofilik

Sumber: Artikel Jurnal Putting Theory and Patterns into Built Environment Practice, 2017

\section{Bangunan Pemulihan Depresi}

Depresi

Depresi adalah satu masa di mana terganggunya fungsi manusia yang berkaitan dengan perasaan yang sedih dan gejala penyertanya, termasuk perubahan pola tidur dan nafsu makan, psikomotor, konsentrasi, anhedonia, kelelahan, rasa putus asa dan tidak berdaya serta bunuh diri. (Sim \& Simanjuntak, 2012)

Berdasarkan American Psychiatric Association (2000) dan Rosenvald, Oei, \& Schmidt (2007) secara umum, terdapat tiga macam depresi yakni: 
a. Depresi ringan/ Mild Depression (kemurungan)

Merasa cemas dan tidak bersemangat, menimbulkan gangguan minor ringan dalam jangka waktu yang lama sehingga seseorang tidak dapat bekerja optimal.

b. Depresi sedang/ Moderate Depression Terjadi ketika depresi ringan berlangsung terus menerus.

c. Depresi berat/ Major Depression

Depresi berat adalah penyakit yang tingkat depresinya parah. Individu mengalami gangguan kemampuan untuk bekerja, tidur, makan, dan menikmati hal yang menyenangkan dan penting untuk mendapatkan bantuan medis secepat mungkin.

Penggunaan standar bangunan yang aman bagi pasien juga diterapkan ke dalam bangunan, seperti penggunaan dekorasi yang sederhana, perabot built in dalam kamar pasien, tinggi lantai bangunan dan tinggi plafon yang aman untuk antisipasi perilaku pasien di luar batas, dan tekstur material bangunan yang halus dengan warna yang menenangkan secara psikologis. Berdasarkan pendekatan dari arsitektur perilaku untuk dapat menciptakan keadaan yang ideal bagi kebutuhan penderita, maka terdapat tiga aspek yang dapat dijadikan pedoman dalam merancang: (Annisa Mutia Sari, 2017)

\section{Privasi}

Penataan massa, ruang, dan sirkulasi akan mempengaruhi privasi penderita. Privasi memberikan perasaan aman dan nyaman. Privasi dibagi berdasarkan kebutuhan interaksi penderita. Penderita gangguan jiwa berat membutuhkan privasi yang tinggi, sedangkan privasi yang tidak terlalu tinggi untuk mendapatkan interaksi dengan orang lain.

\section{Kenyamanan}

Kenyamanan, salah satu dari tiga aspek dipaparkan oleh Gifford, menjadi faktor penting untuk mendukung penyembuhan yang meliputi penghawaan, pencahayaan, aromam dan kebisingan. Penataan ruang juga penting Terdapat kriteria-kriteria yang dianggap ideal menurut Chrysikou (Chrysikou, 2014) yakni Care in the community, Design for domesticity, Social valorization, dan integrated with nature. Perilaku penderita sangat dipengaruhi oleh kenyamanan dalam suatu bangunan maupun ruangan. Dalam hal ini, kenyamanan yang dimaksud meliputi : penghawaan, pencahayaan, aroma dan suara.

a. Penghawaan

Suhu dan polusi udara dapat menimbulkan dua efek, yaitu efek kesehatan dan efek perilaku (Holahan, 1982) . Pemilihan lokasi yang memiliki udara bersih, dingin, dan polusi udara yang rendah, bertujuan mendapatkan penghawaan yang optimal.

b. Pencahayaan

Pengaturan intensitas cahaya dalam ruangan dapat mempengaruhi kondisi mental penderita.

c. Aroma

Indra penciuman manusia mempunyai hubungan langsung yang lebih kuat terhadap memori dan emosi daripada pancaindra yang lain sehingga mampu mempengaruhi kondisi kejiwaan seseorang. Aroma yang menyenangkan akan memberikan efek positif bagi tubuh, seperti mampu menurunkan tekanan darah dan detak jantung, sedangkan aroma yang menyengat dan tidak menyenangkan akan menimbulkan kegelisahan.

d. Kebisingan

Merupakan salah satu pemicu dari perilaku menyimpang pasien gangguan jiwa. Hal ini terjadi karena suara yang tidak menyenangkan atau suara yang ramai membuat otak seseorang terus bekerja tanpa istirahat (Henry \& Heinz , 2008). 
Warna adalah salah satu cara untuk mempengaruhi psikologis kita secara alam bawah sadar. Badan manusia bereaksi sensitif terhadap rangsangan dari masing-masing warna (Gambar 4).

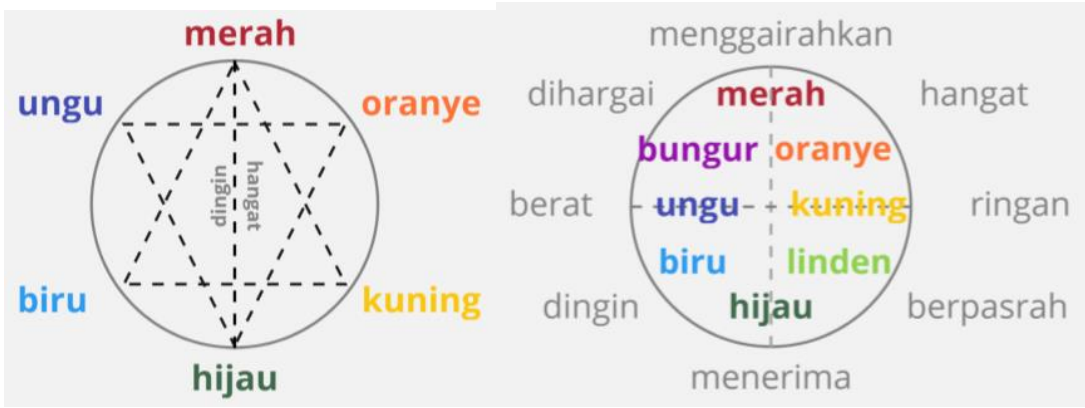

Gambar 4. Pengaruh Warna terhadap psikologis

Sumber: Frick, Heinz/Suskiyatno, Bambang FX. Dasar-dasar eko-arsitektur

\section{Keamanan}

Desain yang aman didapat dari penggunaan interior, material, bentuk, dan tekstur yang tidak mencelakai penderita di dalam bangunan maupun lingkungan sekitarnya (Alread, 2007).

\section{Bangunan Desain Pemulihan Depresi dengan Arsitektur Ekologi}

Hon Yuen, direktur penelitian di departemen terapi okupasi di University of Alabama di Birmingham, menyatakan "Beberapa orang mungkin pergi ke taman hanya untuk menikmati alam, bukannya untuk berolahraga. Namun, hal itu akan membuat akan rileks dan mengurangi stres, serta merasa lebih bahagia," (Ratamanjari, Setyawan, \& Pramesti, 2015)

Dr. Robert Zarr, dokter anak di Washington DC. "Ada perubahan paradigma dalam cara kita berpikir tentang taman, bukan hanya sebagai tempat untuk menciptakan kembali (memori dan rasa ketenangan), tetapi secara harfiah sebagai resep, tempat untuk meningkatkan kesehatan Anda," (Ratamanjari, Setyawan, \& Pramesti, 2015)

International Journal of Environmental Health Research: Menghabiskan 20 menit di halaman rumah maupun di taman, bahkan tanpa berolahraga dan cukup menikmati pemandangan yang ada, bisa meningkatkan kesejahteraan dan perasaan tenang. (Ratamanjari, Setyawan, \& Pramesti, 2015)

Journal of Positive Psychology: Kontak singkat dengan lingkungan alami dengan cepat meningkatkan suasana hati. (Ratamanjari, Setyawan, \& Pramesti, 2015)

Katherine D. Arbuthnott, Campion College, melakukan penelitian terhadap 123 mahasiswa menemukan bahwa peserta yang duduk di ruang terbuka hijau selama 5 menit saja telah menunjukkan peningkatan emosi positif yang signifikan dibandingkan dengan peserta yang duduk di ruang laboratorium tanpa jendela. Namun, jika ingin meningkatkan suasana hati setidaknya menghabiskan waktu 15 menit di ruang terbuka hijau seperti halaman rumah. Ini untuk memperbesar efek positif bagi tubuh. (Ratamanjari, Setyawan, \& Pramesti, 2015)

Esther Sternberg dalam "Healing Space", tempat yang memberikan kebahagiaan dapat mempengaruhi kesehatan dan kebahagiaan itu adalah paradise di mana dapat dilihat bahwa paradise merupakan suasana-suasana alam. (Ratamanjari, Setyawan, \& Pramesti, 2015) Shaun Robinson, yang bertindak sebagai Chief Executive The Mental Health Foundation menyatakan, bahwa meluangkan waktu untuk berdekatan dengan alam sangat baik bagi kesehatan jiwa dan raga. Terbukti, kegiatan ini membuat kehidupan orang-orang lebih bahagia. (Ratamanjari, Setyawan, \& Pramesti, 2015) 
Para peneliti dari University of Plymouth di Inggris, dalam Journal of Environmental Psychology, menemukan bahwa orang yang melakukan wisata alam mingguan memiliki kesejahteraan mental dan fisik yang lebih baik dibanding orang yang tidak berwisata alam. (Al Nasihudin \& Ansori, 2020)

\section{Arsitektur Bangunan Pemulihan di Masa dan Pascapandemi}

Indonesia dapat diprediksikan pandemi baru akan berakhir sekitar 7-10 tahun lagi (Gambar 5), maka dari itu bangunan tentunya akan lebih memperhatikan masalah Kesehatan termasuk di dalamnya adalah kebersihan, jaga jarak, dan pemaksimalan pencahayaan dan pengudaraan alami. (The Straits Times, 2021)

\begin{tabular}{|c|c|c|c|c|}
\hline Indonesia & 60,433 & $>10$ years & $1,134,854$ & 31,202 \\
\hline Global & $4,540,345$ & 7 years & $104,869,210$ & $2,284,221$ \\
\hline
\end{tabular}

Covid-19 dapat menempel pada material tertentu cukup lama dan dapat juga bertahan lama pada ruang ber-AC dan ruang yang tidak mendapatkan cahaya yang cukup, dan virus ini menyebar melalui droplet, kontak langsung, ataupun droplet yang sudah ada menempel pada material/elemen bangunan. New normal dalam perancangan arsitektur perlu memasukkan unsur yang mengadopsi anjuran pemerintah yakni jaga jarak, cuci tangan, dan pakai masker.

a. Tinjauan berdasarkan ruang

Desain lebar jalan sesuai aturan jaga jarak yaitu 1 meter. Jika lebar dasar 1 orang adalah $60 \mathrm{~cm}, 2$ orang menjadi $120 \mathrm{~cm}+100 \mathrm{~cm}$ (social distancing) maka lebarnya menjadi $220 \mathrm{~cm}$. Ruang per orang sesuai standar sebelum new normal per orang $4 \mathrm{~m}^{2}$, namun sekarang menjadi 2 x yaitu $8 \mathrm{~m}^{2}$. (Purwono, 2020)

b. Tinjauan berdasarkan Material

Pemilihan material menjadi hal penting sebagai upaya meminimalisasi transmisi virus pada benda-benda yang mungkin terpapar virus covid-19. (Purwono, 2020)

c. Tinjauan berdasarkan Softscape

Softscape merupakan unsur tanaman. Virus dapat bertahan lama pada lingkungan yang sejuk dan nyaman, maka bila berkumpul di bawah merupakan kondisi riskan karena kemungkinan virus dapat bertahan lebuh lama. Dikatakan, paparan sinar matahari yang kuat selama 30 menit bisa membunuh atau memusnahkan virus. (Sagita, 2020) Perencanaan dan perancangan softscape harus mempertimbangkan jenis tumbuhan yang tepat

d. Tinjauan berdasarkan fisika bangunan

Diperlukan jendela untuk mendapatkan cahaya matahari yang cukup dan sirkulasi udara yang baik. Penggunaan AC parsial lebih baik daripada AC sentral. Sanitasi dan pengolahan limbah harus dipisahkan antara limbah masker dan limbah rumah tangga. (Purwono, 2020)

\section{METODE}

Metode yang dipakai adalah metode kualitatif yakni metode studi kasus berdasarkan teori-teori pada kajian literatur di atas, maka didapatkan indicator penelitian untuk analisis adalah: prinsip ekologi, metode simbiosis dan desain biofilik. Tiga metode yang digunakan dalam mendesain tersebut dipilih karena sesuai dengan tujuan untuk membantu pemulihan depresi. 


\section{DISKUSI DAN HASIL}

\section{Bangunan dengan konsep Ekologi}

Penerapan Beyond Ecology pada bangunan merujuk pada aspek-aspeknya yang pertama adalah Energy and emission yang diterapkan melalui material bangunan yang terbuat dari panel jamur yang dapat menyerap karbon $2 x$ lebih banyak daripada material lain pada umumnya, Adaptation terdapat pada bangunan yang beradaptasi dengan kondisi pandemi. Resilience diterapkan pada bentuk bangunan panggung dan desain terbuka untuk meminimalisasi penyebaran virus. Sustainable digital diterapkan pada penampung air hujan berupa pipa-pipa yang diinstalasikan pada 'Terawang' (Menara-menara berbentuk payung), greenroof, dan sistem biopori. New technology terletak pada dan pemanfaatan mikro algae sebagai penerangan lampu taman. Terakhir, Context terletak pada rancangan 50\% tapak merupakan area resapan hijau (Gambar 6 )
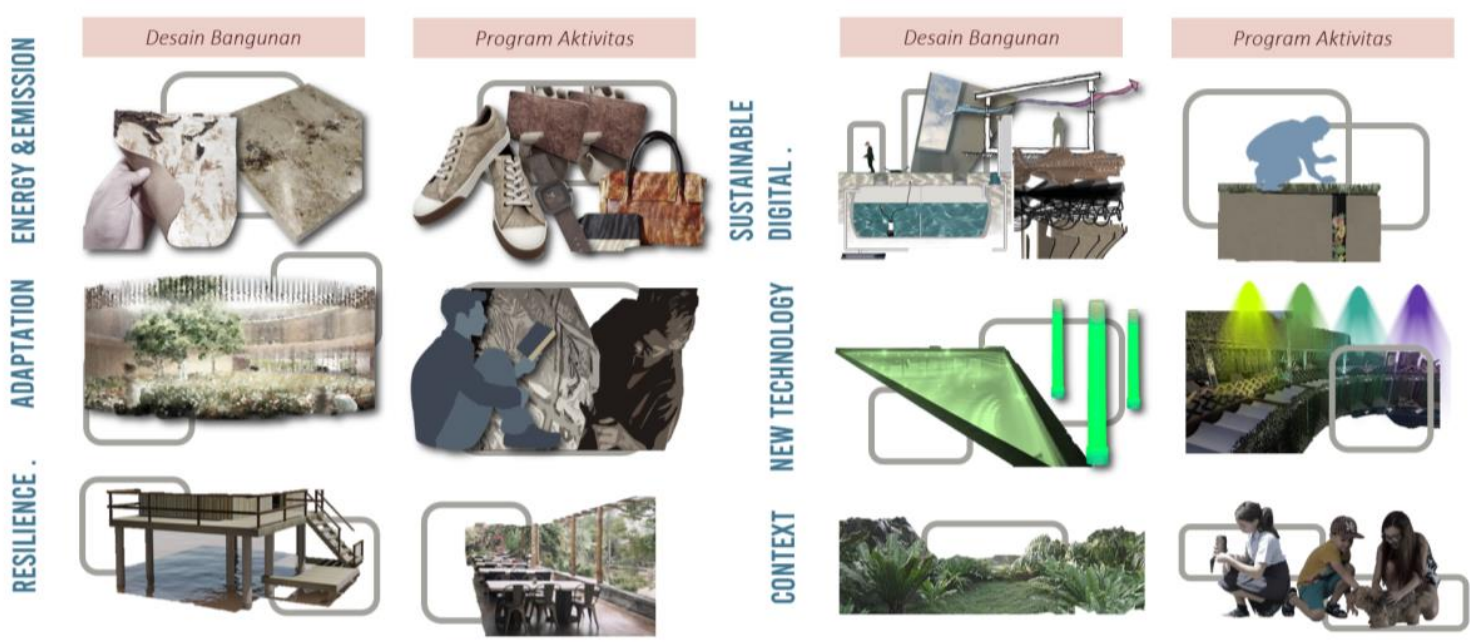

Gambar 6. Aspek Beyond Ecology yang diterapkan pada bangunan Sumber: Penulis 2021

\section{Bangunan dengan metode Simbiosis}

Sesuai dengan prinsip ke-enam menurut Kisho Kurokawa yakni Symbiosis of Man and Nature maka rancangan bangunan memaksimalkan hubungan antara lima kingdom makhluk hidup yang ada di lingkungan bangunan, yakni: manusia, hewan, tumbuhan, jamur dan algae. Adanya upaya manusia untuk menjaga lingkungan hidupnya menciptakan kualitas lingkungan yang lebih baik, dan adanya kegiatan tersebut juga memberikan efek menyembuhkan bagi manusia. Selain itu, manfaat dari adanya hewan dan tumbuhan berdampak baik bagi ekologi, algae dapat dimanfaatkan sebagai sumber energi, dan jamur digunakan sebagai panel dinding bangunan. (Gambar 7)

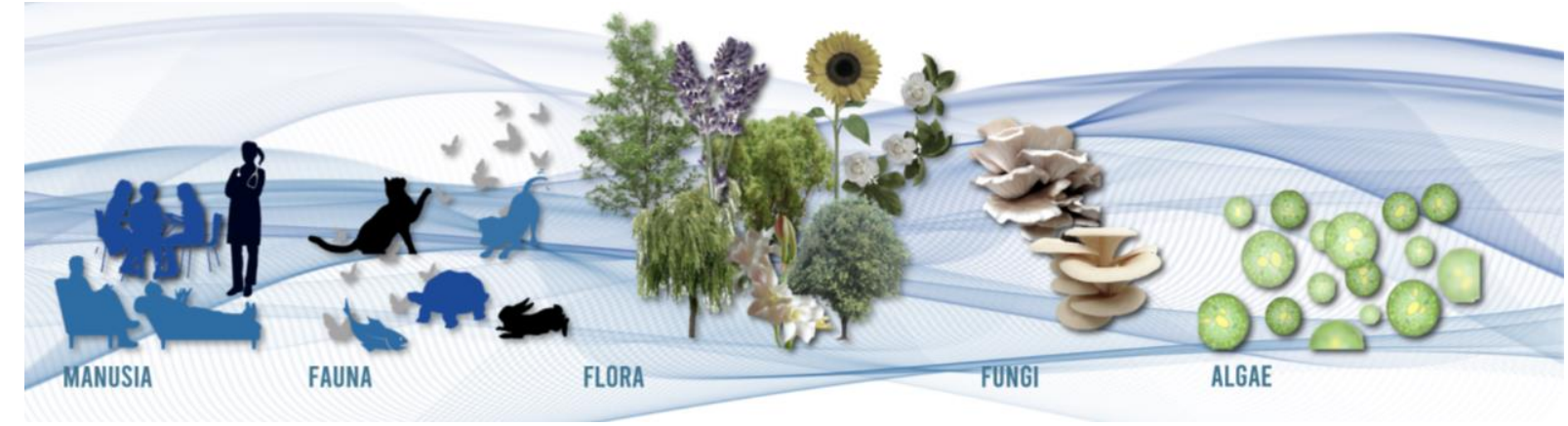

Gambar 7. Aspek Simbiosis

Sumber: Penulis 2021 


\section{Bangunan dengan desain Biofilik}

Sepuluh aspek biofilik yang dapat diterapkan bangunan diantaranya adalah elemen air dengan adanya hidroterapi dan kolam, ritme keteraturan dari masa bangunan rawat inap, permainan cahaya pada kamar dan ruang pengelola, pola biomorfik dari kisi-kisi parametrik, memaksimalisasi visual alam dengan membuat ruang makan semi outdoor, menghubungkan dengan sistem alam dengan penanaman bunga matahari, pemakaian material kain untuk stimulai sensorik, menjadi habitat bagi burung untuk memaksimalkan audio, penggunaan material alam yang beragam dan pengoptimalan aliran udara. (Gambar 8)
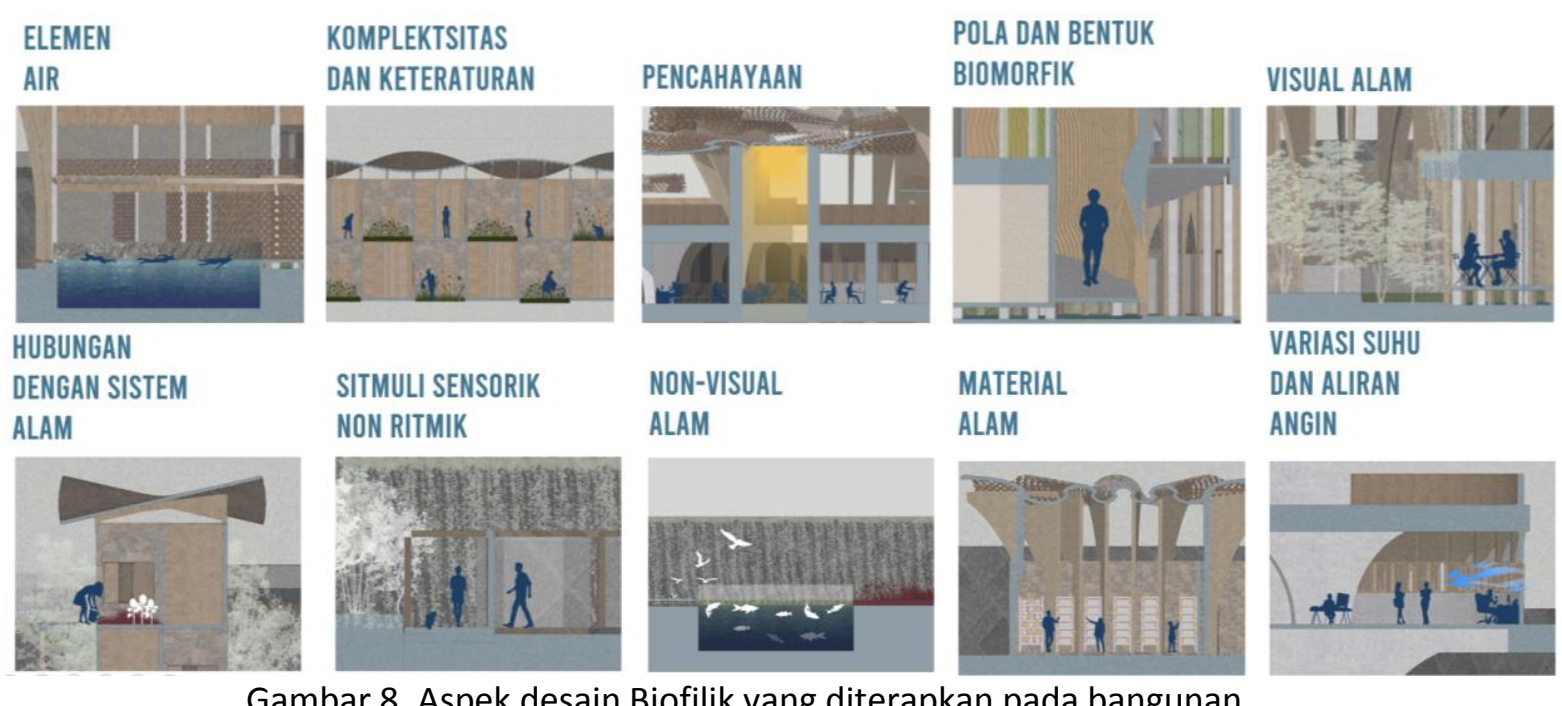

Gambar 8. Aspek desain Biofilik yang diterapkan pada bangunan Sumber: Penulis 2021

Salah satu yang menonjol dari bangunan Derana ini adalah 'Terawang' yang dapat menampung air hujan untuk digunakan Kembali. Selain itu, pola anyaman yang berada di lapisan terluar memberikan pembayangan untuk peneduhan dan memberikan permainan cahaya yang menarik bagi pasien. (Gambar 9 dan 10)

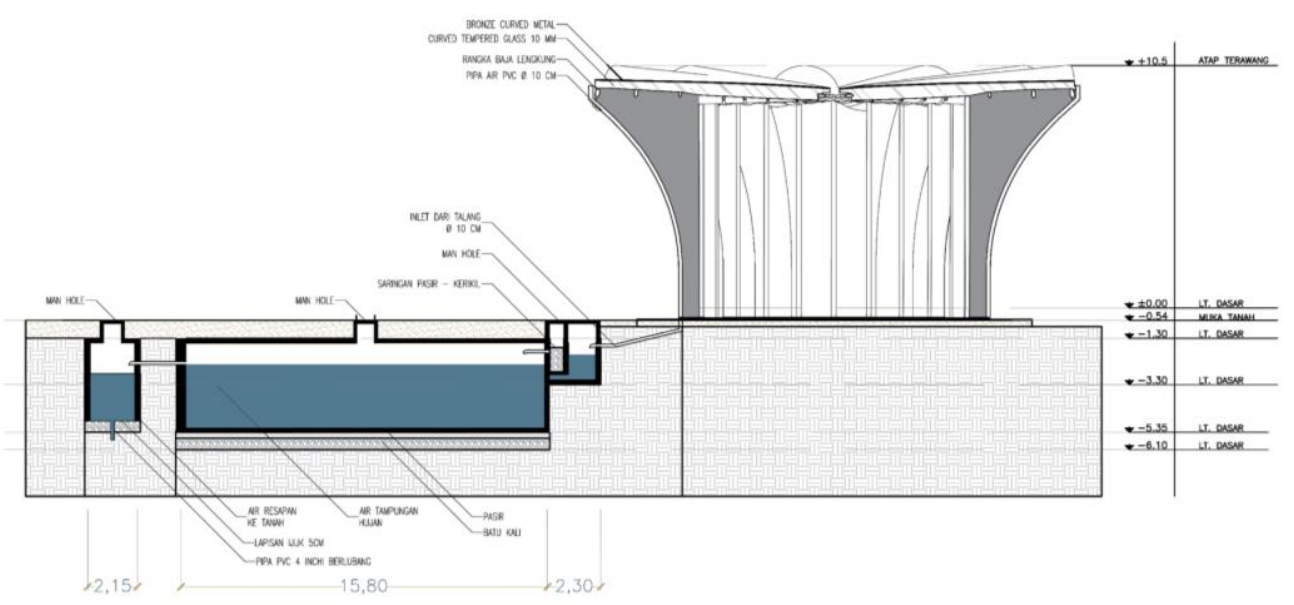

Gambar 9. Potongan Sistem penampung air hujan Sumber: Penulis 2021

\section{Pasien Depresi}

Program yang disediakan untuk pasien depresi dibedakan sesuai dengan macamnya. Untuk depresi ringan diperkenankan untuk rawat jalan atau rawat inap, depresi sedang diperkenankan untuk rawat inap, dan depresi berat rawat inap khusus isolasi. 
Secara eksterior, desain bangunan terlihat inklusif dari pintu masuk, namun bangunan memiliki view terbuka erat dengan alam di area belakang bangunan. Aksen lengkung yang merupakan salah satu aspek desain biofilik mendominasi bangunan dikarenakan memberi efek baik untuk penyembuhan pasien. (Gambar 10)

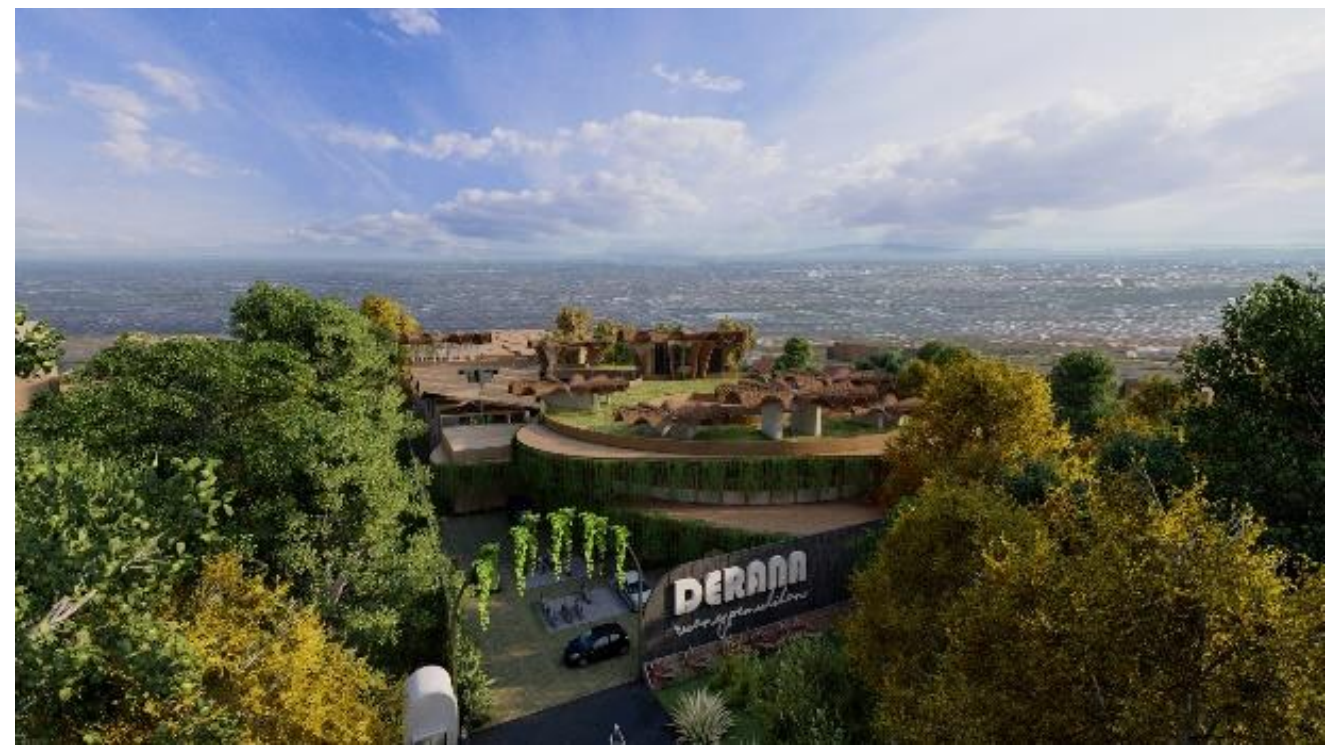

Gambar 10. Visualisasi perspektif eksterior Sumber: Penulis, 2021

\section{Desain Pemulihan Depresi dengan Arsitektur Ekologi}

Desain Healing Architecture dengan adanya Cahaya matahari memberi kesan vital dalam ruang, aroma bunga-bunga yang ditanam di taman kecil sebelah kamar. Gardenia, lavender, sedap malam memberikan efek menenangkan. Skylight memberikan efek vital dalam ruang, aksen gelombang merupakan bentuk biomorfik agar ruangan tidak terlalu kaku. Warna-warni pada kaca memberikan stimulus baik untuk pasien depresi. (Gambar 11)

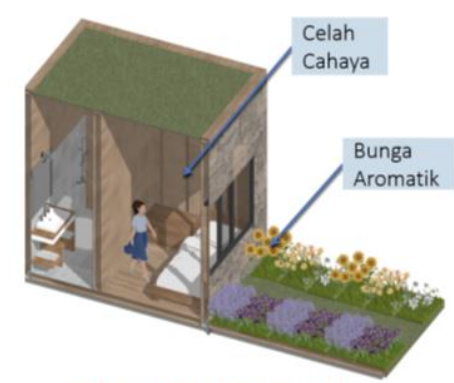

DESAIN KAMAR HUNIAN DEPRESI RINGAN-SEDANG

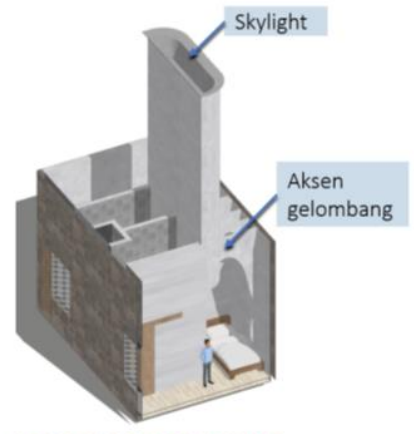

DESAIN KAMAR HUNIAN DEPRESI BERAT

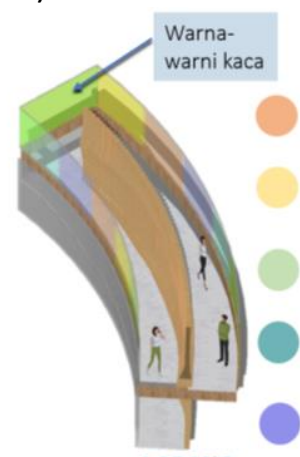

LORONG PELANGI

Gambar 11. Desain Healing Architecture untuk Pasien Depresi

Sumber: Penulis, 2021

\section{Arsitektur Bangunan Pemulihan di Masa dan Pascapandemi}

Desain bersifat semioutdoor diterapkan pada area makan, dapur, hidroterapi, dan juga meditasi untuk meminimalisasi transmisi virus. Ruang kegiatan seperti melukis, workshop, membatik, dan amphiteater disusun agar posisi duduk berjauhan. Ruang galeri dan edukasi dibuat 1 alur agar pengunjung tidak saling berhadapan (Gambar 12) 


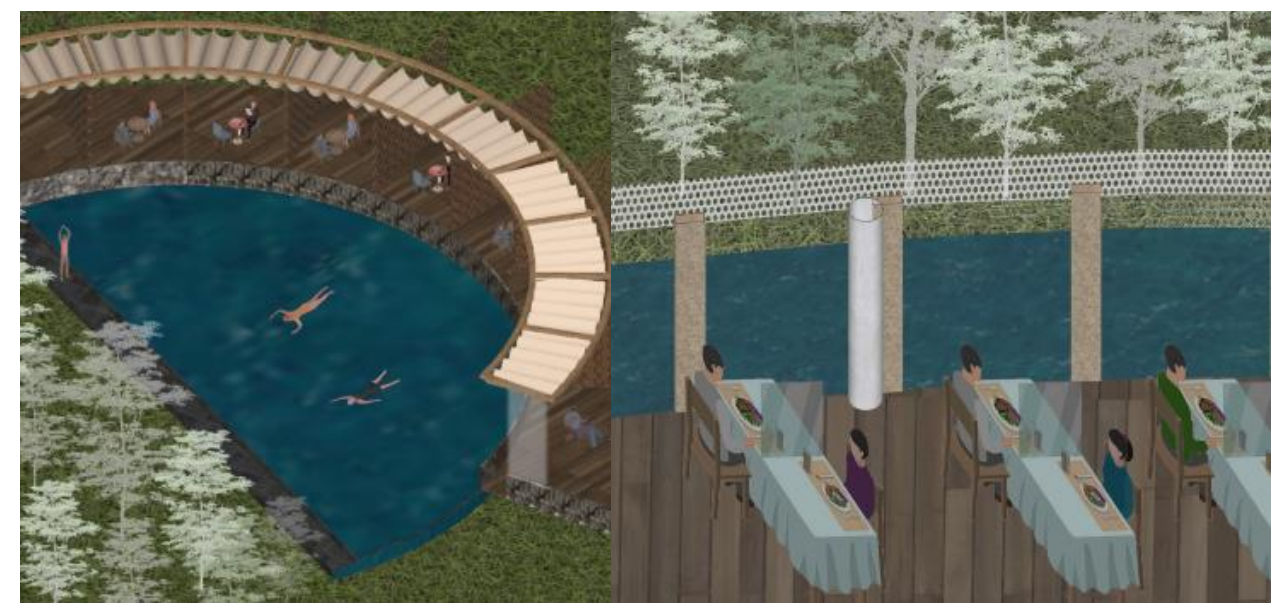

Gambar 12. Desain hidroterapi dan Area makan Sumber: Penulis, 2021

\section{KESIMPULAN DAN SARAN}

Krisis ekologi dan kesehatan mental yang kian semakin parah menjadikan dasar hadirnya rancangan 'Derana' yang bervisi dapat menurunkan angka pengidap depresi, menyelamatkan jiwa-jiwa yang mungkin saja dapat hilang, dan membukakan mata bagi masyarakat yang masih menganggap enteng depresi. Bangunan dirancang sesuai dengan metode simbiosis yang dapat menciptakan keuntungan bagi kedua belah pihak untuk menciptakan lingkungan yang lebih baik dengan melibatkan makhluk hidup berupa manusia, hewan, tumbuhan, fungi, dan alga.

Bangunan juga berpegang prinsip ekologi yang diterapkan pada bangunan. Berdasarkan pada healing architecture dan desain biofilik, program menarik, komunitas yang suportif, tapak yang kondusif, menjadikan ruang rehabilitasi Derana berbeda dengan fasilitas kesehatan pada umumnya. Sesuai dengan visi dan misi yang telah diutarakan sedari awal, dengan bersandar pada metode ekologi, simbiosis kiranya rancangan proyek ini dapat menjadi gagasan menarik serta solusi dalam menghadapi depresi terutama di situasi pandemi.

\section{REFERENSI}

Al Nasihudin, A., \& Ansori. (2020). Jangan Lupa Wisata Alam Biar Mental Sejahtera dan Sehat Jasmani. Jakarta: Liputan6.

Alread, J. d. (2007). Life Safety. Dalam Design Tech: Building Science for (hal. 41). Oxford: AIA.

Annisa M. S., M. W. (2016). Pusat Rehabilitasi Gangguan Jiwa dan Skizofrenia dengan pendekatan arsitektur perilaku di Kabupaten Kulonprogo. Jurnal Arsitektur, 188-196.

Annisa M. S., M. W. (2017). (Annisa Mutia Sari, Pusat Rehabilitasi Gangguan Jiwa dan Skizofrenia dengan pendekatan arsitektur perilaku di Kabupaten Kulonprogo. Jurnal Ilmiah Arsitektur dan Lingkungan Binaan, 15(1), 188-196. doi:doi.org/10.20961/arst.v15i1.12076

Azizah , U. I., \& Jaya, A. M. (2016). Ruang Publik untuk Kesehatan Mental . JURNAL SAINS DAN SENI ITS.

Chrysikou, E. (2014). Architecture for psychiatric environments. London.

Della R., H. S. (2015). Rumah Sakit jiwa Dengan Konsep Healing Environment Di Kota Semarang. Jurnal Arsitektur.

Downton, P., Jones, D., Zeunert, J., \& Roos, P. (2017). Biophilic Design Applications: Putting Theory and Patterns into Built Environment Practice.

Frick, H. (1998). Seri Eko-Arsitektur 2 Arsitektur Ekologis. Yogyakarta: Kanisius.

Henry, F., \& Heinz , F. (2008). Atap Bertanaman Ekologis dan Fungsional. Yogjakarta: Kanisius.

Holahan, C. J. (1982). Environmental Psychology. Indiana: Random House.

Indonesia, CNN. (2020). WHO: Pandemi Covid-19 Menghancurkan Kesehatan Mental. Jakarta: CNN Indonesia. 
PDSKJI. (2020, Mei 14). Indonesian Psychiatric Association. (Architecture by Birds and InsectsPerhimpunan Dokter Spesialis Kedokteran Jiwa Indonesia) Dipetik Februari 12, 2021, dari http://pdskji.org/home

Purwono, R. (2020). Adaptasi Disain Arsitektur dan Arsitektur Lanskap dengan Adanya Kehidupan Sosial Baru setelah Pandemi Covid-19. Jurnal Universitas, 1(Covid-19), 14.

Ratamanjari, D., Setyawan, H., \& Pramesti, L. (2015). Rumah Sakit Jiwa dengan Konsep Healing Environment di Kota Semarang. Jurnal Arsitektur.

Sagita, N. S. (2020, Juni 23). Detik.com. (Detik.com) Dipetik Februari 26, 2021, dari https://health.detik.com/berita-detikhealth/d-5064447/paparan-sinar-matahariselama-30-menit-diklaim-bisa-bunuh-corona

Sim, \& Simanjuntak, J. (2012). Merawat Kesehatan Mental Keluarga. Tangerang: Yayasan Pelikan.

Simanjuntak, J. (2012). Merawat Kesehatan Mental Keluarga. Tangerang: Yayasan Pelikan.

Sutanto, A. (2020). Peta Motode Desain. Jakarta: Universitas Tarumanagara.

The Straits Times. (2021, Februari 6). When will life return to normal? In 7 years at current Covid19 vaccination rates. (The Straits Times) Dipetik Februari 12, 2021, dari https://www.straitstimes.com/world/when-will-life-return-to-normal-in-7-years-atcurrent-covid-19-vaccination-rates

Trisno, R., \& Lianto, F. (2019). Realization of Hybrid Concept and Symbiosis in Green Open Space (RTH) at Housing Complex RW (Neighborhood Councils) Pluit, Jakarta Utara, Indonesia. IOP Conf. Series: Journal of Physics, 1179, 1-7. doi:10.1088/1742-6596/1179/1/012165

Wuaten, L. V., Siregar, F. O., \& Takumansang, E. D. (2014). GRAHA PECINTA ALAM (GRAPALA) SIMBIOSIS DALAM ARSITEKTUR, KISHO KUROKAWA' . Jurnal Arsitektur DASENG UNSRAT Manado, 1-9.

Ziyad Nimr Ajeel1, A. A. (2019). Symbiotic Architecture: Symbiotic as a Strategy in the Production of. International Research Journal of Engineering and Technology (IRJET), 06(01), 13. 
